\title{
The Formation of a Digital Society on the Example of Japan and the Republic of Korea
}

\author{
Svetlana Korobko \\ Institute of economics and \\ management \\ Kemerovo State University \\ Kemerovo, Russia \\ dashuka1997@rambler.ru
}

\author{
Ludmila Sagdeeva \\ Institute of economics and \\ management \\ Kemerovo State University \\ Kemerovo, Russia \\ slszmo@mail.ru
}

\author{
Svetlana Savintseva \\ Institute of economics and \\ management \\ Kemerovo State University \\ Kemerovo, Russia \\ ssa-svet@mail\&ru
}

\begin{abstract}
The article discusses the foreign experience of the leading countries in the development of information and communication technologies (ICT) in Japan and Korea. These countries are of the same region with similar economic models that have traveled at different times and with varying degrees of success from an agrarian country to an industrial power, where a significant number of high-tech industries are developing. The basis for the introduction of digital technologies was the National Innovation Systems, that include a community of the following institutions: government, business and the academic sector. Despite different starting conditions, ICT policies in Japan and Korea in the 2000s had the same priorities in narrowing the digital divide within the country and in comparison, with other countries, providing every citizen with access to high-speed broadband and using ICT to solve the country's socio-economic problems. The global economic situation after the global financial crisis, regional competition, domestic problems, as well as the emergence of promising technologies are pushing both countries - Japan and the Republic of Korea - to seek new opportunities to increase their competitiveness in the global digital economy. This process is based not only on technological activity but also on the development and implementation of institutional and structural reforms, aimed at improving conditions for the creation, dissemination and effective use of digital technologies within the country. The experience of these countries seems significant for Russia for further cooperation in creating a single digital space in East Asia.
\end{abstract}

Keywords: digital technologies, information and communication technologies, national innovation system, competitiveness, digitalization of society in Japan and the Republic of Korea

\section{INTRODUCTION}

By the end of the second decade of the 21 st century, it has become unambiguously clear that the development and dissemination of digital technologies is an inevitability that needs from us to be prepared for, and an opportunity that can be used as the most important driver for further economic development. Some countries are investing more in information and communications technology (ICT) than others. Thus, according to the ICT Development Index, 2017, the top ten countries included: Iceland, the Republic of Korea, Switzerland, Denmark, Great Britain, Hong Kong (China), the Netherlands, Norway, Luxembourg and Japan
[1]. Among the countries listed, it makes sense to consider Japan and the Republic of Korea, because these are countries of the same region with similar economic models that have traveled at different times and with different successes from an agrarian country to an industrial power, where a significant number of knowledge-intensive industries are developing. In 2017, the share of the ICT sector in Japan's GDP was $6 \%$, and in Korea - $10.3 \%$.

In 2016, at the Eastern Economic Forum (WEF) V.V. Putin voiced the idea of creating a single digital space in East Asia, and at the WEF in 2017, Minister of Economic Development of the Russian Federation M.S. Oreshkin and Minister of Economy, Trade and Industry of Japan H. Sako signed a joint statement on cooperation in the field of digital economy. Given the state of the competitive environment in the region, it is foolish not to expect that other countries of the region, including the Republic of Korea, China, Singapore and India, may join the cooperation. This means that Russia can not only borrow the experience of other countries in the region, but also share its own, especially given the successes of Russian specialists in mathematics and system programming.

The basis for the implementation of digitalization in all spheres of society is the National Innovation System (NIS). The development of this concept of NIS was carried out by B.A. Lundvall [2], R. Nelson [3], K. Freeman [4] and others. There are many definitions for NIS, so the scholars chose three main ones, which are indicated in the OECD report on NIS [5]:

1. NIS - the elements and interactions between them in the process of production, dissemination and use of new, economically useful knowledge located or rooted in the borders of a nation state (according to B.A. Lundvall).

2. NIS - a set of institutions whose interaction determines the innovative performance of national firms (according to R. Nelson).

3. NIS - a network of institutions in the public and private sectors, whose activities and interaction initiate, import, modify and disseminate new technologies (according to K. Freeman). 
There are three structural elements of the NIS. The state, which broadcasts its scientific, technological and innovation policy to economic agents within the country. The business that is represented by national companies of various sizes and specializations, mainly with innovative potential. The academic sector - in particular, national universities and national research institutes - which trains personnel with fundamentally new skills and conducts such studies, on the basis of which innovations can be introduced and monetized.

\section{RESEARCH PRoBlem}

The digitalization of society in the Republic of Korea was studied by J. F. Larson [6], Gene Dalen [7], Lee Sanming [8] and others. J. F. Larson explained the success of the Republic of Korea's ICT infrastructure policy. In particular, he noted that the success of the Republic of Korea is associated with long-term planning, the development of an educational system focused on the information age. In addition, he predicts that the Republic of Korea could become a digital leader in the foreseeable future. Gene Dalen argues that the current boom in digital technology in the Republic of Korea is inextricably linked to its digital culture. So, he focuses only on a few ICTs, in particular the Internet, broadband and smartphones, and considers digital culture in terms of ICT policies, internal competition and culture. Lee Sanming examines the Republic of Korea as an example of how the spread of smart devices is narrowing or widening the digital divide.

The digitalization of society in Japan was researched by T. Nishida, J. B. Peak, A. Sarkar [9], T. Murakami [10] and others. T. Nishida and his co-authors J. B. Peak and A. Sarkar analyzed the digital divide in 47 prefectures in Japan on the basis of demographic, economic, infrastructural, educational and innovative factors. T. Murakami studied Japan's national ICT strategies ("e-Japan" and "u-Japan") and how they were borrowed and applied in the Republic of Korea ("e-Korea" and "u-Korea").

Currently, a new paradigm is being formed in Russia, based solely on theories of sustainable development and the knowledge economy, where digitalization is the main mechanism for its implementation [11]. Russia, as another regional player, could also draw from the Equations

experience of Japan and the Republic of Korea interesting ideas for implementing its own Digital Economy program, approved in 2017. This implies not so much the transposition of the experience of the countries considered in this study on Russian soil, but its creative rethinking and the creation of original political measures based on it. For the Russian economy this is an impetus for economic growth, as digitalization accelerates production and exchange processes, increases the level of competition and contributes to the well-being of society [12].

We should consider the formation of processes for digitalization of society in Japan and the Republic of Korea. The ICT revolution in the mid-1990s has contributed significantly to the creation of an ecosystem for the digital economy. Japan and the Republic of Korea, as countries that have long been catching up with Western countries, borrowing and adapting their technologies, have got a chance to use their advantage of late industrialization and break ahead in the development of ICT.
In order to develop the digital economy at the level of technology of the fourth industrial revolution, it is necessary to maximize the use of the Internet and mobile communications in the country, including through fifthgeneration $(5 G)$ broadband connections. And it is the East Asian countries that are leading in this regard today. So, exactly their standards and time frames are being developed for the implementation of $5 \mathrm{G}$ wireless networks. According to some estimates, by 2025 in Asia there will be 670 million using $5 \mathrm{G}$ people, which will be $60 \%$ of all $5 \mathrm{G}$ connections [13]. According to experts, $5 \mathrm{G}$ technologies are designed to make the use of the Internet of things (IW) technology as efficient as possible. It was also predicted that they would provide higher bandwidth compared to previous generation communication standards (3-4G), which in turn would further expand Broadband capabilities [14].

But even before the advent of $5 \mathrm{G}$ technology, the efforts of the governments of Japan and the Republic of Korca to bridge the digital divide compared with other countries and between regions within the country were very active. For example, back in 2001, the e-Japan strategy was announced in Japan. It was aimed at making the country a world leader in the distribution of the Internet, mobile communications and other ICTs until 2005. In particular, the strategy envisaged the development of network infrastructure with a focus on the transition from narrowband to broadband networks, since the latter can significantly speed up connections and improve the capabilities of the Internet for use in various fields of life.

The second phase of the implementation of this strategy under the name "e-Japan II" was adopted in 2003 and was intended to take another step forward - to shift the focus from developing network infrastructure to expanding the use of ICT, in particular for the development of e-commerce and e-government. As part of this strategy, seven areas were selected in which the use of ICT was considered the highest priority. These were medical services, food, livelihoods, SMEs, education, employment and labor and public services. However, this strategy was also more technical in nature, as the goal was to expand the use of ICTs rather than to solve the urgent social problems [10].

The following targets were indicated: by 2005, 30 million households were supposed to switch to high-speed Internet and 10 million households in ultra-high-speed Internet. As for 2005, 46.3 million households used highspeed Internet and 35.9 million households used ultra-highspeed Internet. Thus, it can be stated that the success of the policy regarding the distribution of network capabilities has even exceeded expectations [15]. Nevertheless, it turned out that with the fast expansion of network infrastructure the demand for network services was growing slowly, the digital divide is only getting deeper. Therefore, the government had to slightly change focus in the following plans.

On this wave in 2004 , a fundamentally new strategy " $u$ Japan" appeared, the meaning of which was to ensure that by 2010 even small and remote places in the country were provided with access to broadband (both wired and wireless). It was supposed that such a policy should create such conditions of a network environment where citizens do not think about access to the Internet and mobile communications and can receive network services without interruption, even in rural areas. In addition, it was assumed 
that ICTs should not only be used, but also help to solve social problems, including problems of low birth rates and the aging of society. Another feature of the u-Japan strategy was concerned over the negative effects of ICTs, including violation of information security and access by attackers to confidential data. The solution to these concerns, as conceived by the developers of the strategy, was to improve the user environment for using the network [16].

Thus, one can trace the general trend of Japanese ICT policy. In 2001, it seemed necessary to create a network infrastructure with the transition from narrowband networks to faster and more uninterrupted broadband networks. In the future, taking into account the state of the network services market at that time, the focus was shifted to expanding the possibilities of using network services throughout the country to help solving the social problems facing the country.

At the same time as Japan did, the Republic of Korea adopted the ideas of informatization of society and applied them in its own way. So, in 2002, the e-Korea strategy was announced, which was designed to achieve leadership in the field of ICT and bridge the digital divide by 2006 [17]. The following tasks were set as part of the strategy:

1. provide all citizens with maximum access to the Internet and mobile communications;

2. increase the country's international competitiveness by promoting the informatization of all sectors of the economy;

3. ensure economic growth by promoting the use of ICTs and building network infrastructure;

4. take a leading position in the global market through regional cooperation in the field of ICT (primarily with Japan and China).

Regarding the expansion of the use of ICT in the country, it was planned to increase the percentage of Internet use in the country to $90 \%$ by 2006 . According to the strategy, to achieve this level, it was necessary to increase access to ICT education, including for older people and people with disabilities, and to increase public access to high-quality broadband services.

In 2006, Korea appeared similar to the Japanese plan "uKorea", which was calculated until 2010. The main goal, as in Japan, was assigned to maximize the access of the population to ICT throughout the country. To this end, the IT839 strategy was developed, according to which it was necessary to combine the services, infrastructure and growth engines of that time into one infrastructure of the ICT sector. In this regard, targets were set to achieve the objectives. For example, regarding the distribution of a high-speed broadband network (100 Mbit per second), it was planned to increase the number of subscribers by 20 million by 2010 [10].

\section{RESEARCH RESULTS}

In general, the ICT policy in Japan and Korea in the 2000 s had the same priorities: narrowing the digital divide within the country and in comparison, with other countries, providing each citizen with access to high-speed broadband and using ICT to address the country's socio-economic problems. It was with this "background" that both countries came to the development of technologies for NDV.

Thus, despite the different starting points for rapid economic growth in Japan and the Republic of Korea, the world economy after the global financial crisis, regional competition, internal problems, and the emergence of promising technologies are pushing both countries to look for new ways to increase their competitiveness in the world markets of the digital economy. This process is based not only on technological activity but also on the development and implementation of institutional and structural reforms, aimed at improving conditions for the creation, dissemination and effective use of digital technologies within the country.

\section{References}

[1] G.I. Abdrakhmanova, K.O. Vishnevsky, G.L. Volkova, L.M. Gokhberg, and et al., Indicators of the digital economy: 2018: statistical collection. And 60 NAT. research. UN-t "Higher school of Economics", Moscow: HSE, 2018.

[2] B-Å. Lundvall (ed.), National Innovation Systems: Towards a Theory of Innovation and Interactive Learning. Pinter, London, pp. $342,1992$.

[3] Richard R. Nelson, National Innovation Systems: A Comparative Analysis. Oxford University Press, pp. 554, June 1993.

[4] C. Freeman, (1995), "The National System of Innovation in Historical Perspective", Cambridge Journal of Economics, no. 19, pp. 5-24, 1995.

[5] C. Frecman, Technology Policy and Economic Performance: Lessons From Japan. Pinter, London, pp. 155, 1987.

[6] OECD, National Innovation Systems. Paris, p. 10, 1997.

[7] F. Larson James, "Network-centric Digital Development in Korea: Origins, Growth and Prospects", Telecommunications Policy, vol. 41 , iss. 10, pp. 916-930, 2017.

[8] Dal Yong Jin, "Construction of Digital Korea: The Evolution of New Communication Technologies in the 21 st Century", Media, Culture \& Society, vol. 39, iss. 5, pp. 715-726, 2017.

[9] Seung Min Lee, "Smart Divide: Paradigm Shift in Digital Divide in South Korea", Journal of Librarianship and Information Science, vol. 48, iss. 3, pp. 260-268, 2014.

[10] T. Nishida, J.B. Pick, and A. Sarkar, “Japan's Prefectural Digital Divide: A Multivariate and Spacial Analysis", Telecommunication Police, vol. 30, iss. 11, pp. 992-1010, 2014.

[11] T. Murakami, “Japan's National IT Strategy and the Ubiquitous Network", NRI Papers, no. 97, 2005 [Electronic resource]. Available at: $\quad$ https://www.nri.com/global/opinion/papers/2005/pdf/ np200597.pdf (Accesssed: 15.10.2019).

[12] A.I. Zaytseva, L.S. Sagdeeva, and S.A. Savitseva, "Formation of Knowledge Economy in the "recourse Type" Regions", IOP Conference Series: Earth and Environmental Science, Institute of Physics Publishing, vol. 272, 2019. DOI: 10.1088/17551315/272/3/032206.

[13] S.M. Korobko and L. S. Sagdeeva, "Human capital as a factor of sustainable development in the digital economy", Bulletin of the Academy of knowledge, no. 2 (31), pp. 211-214, 2019.

[14] The Future of 5G Networks in Asia, 25 October 2017 [Electronic resource]. Available at: https://www.thefastmode.com/expertopinion/l 1475-the-future-of-5g-networks-in-asia (Accessed: 19.10.2018).

[15] S. Jankowski and et al., "5G: How 100x faster wireless can shape the future", Goldman Sachs, , pp. 1, 5 and 21-25, 18 April 2016.

[16] Contributing to Future Deployment of e-Japan Strategies, MIC [Electronic resource]. Available at: http://www.soumu.go.jp/menu_seisaku/ict/u-japan_en/new_outline 01.html (Accessed: 15.05.2019).

[17] The National ICT Strategies in Japan are evolving from "e" to " $u$ ", MIC [Electronic resource]. Available at: 


\section{PRESS}

http://www.soumu.go.jp/menu_seisaku/ict/u-

japan en/new outline0lb.html (Accessed: 15.10.2019).

[18] E-Korea Vision 2006, Ministry of Science and ICT, 2002 [Electronic resource]. Available at: file://C:/Users/User/Downloads/eKorea $\% 20$ Vision $\% 202006 \% 20$ -

\%20The\%20Third\%20Master\%20Plan\%20for\%20Informatization\% 20Promotion\%20-2002-2006.pdf (Accessed: 15.10.2019). 